\title{
Consumer Perspective on Conventional vs. Islamic Fashion E- Commerce: An Empirical Study
}

\author{
Salma Amelia Dina,a and Sri Rahayu Hijrah Hati, ,, ${ }^{*}$ \\ ${ }^{1}$ Islamic Business Undergraduate Program Faculty of Economics and Business Universitas \\ Indonesia-Depok, Indonesia \\ ${ }^{2}$ Management Department Faculty of Economics and Business Universitas Indonesia-Depok, \\ Indonesia \\ asalma.amelia@ui.ac.id, bsri.rahayu72@ui.ac.id \\ ${ }^{*}$ Corresponding author
}

\begin{abstract}
Keywords: Attitude, purchase intention, e-commerce, Islamic
Abstract. The Muslim population is currently being underserved in the conventional marketplace; however, Muslims are enthusiastic to purchase products that are acceptable to their lifestyle, especially fashion products. The current study compares the perception, attitude and intention of the Muslim consumer with respect to conventional and Islamic e-commerce based on pre-purchase and transaction-related services such as product pricing, support of product search evaluation, web appearance, billing and paying mechanism, delivery arrangement, security and privacy. Data were collected from 319 Muslim women who were exposed to both conventional and Islamic fashion ecommerce.
\end{abstract}

\section{Introduction}

Islamic fashion is a phenomenon rooted in the combination of a set of Islamic laws (in which the necessity to cover specific body parts is required) and growing needs and wants that include specific fashion products in the wider fashion industry. The Islamic fashion industry is currently growing rapidly and is expected to reach $\$ 327$ bn by 2020 [1]. Despite Islamic fashion sales online still being relatively small, in 2013 , Islamic fashion grew at a rate of $25.4 \%$ compared to conventional fashion e-commerce, which only reached 5.8\% [2]. Even though growth of Islamic fashion e-commerce is high, Muslim consumers' needs and wants with respect to Islamic fashion are still underserved in the conventional market [2]. The current study aims to compare conventional and Islamic e-commerce from the Muslim consumer's perspective based on pre-purchase and transaction-related services, navigation experiences, attitude towards the web and purchase intention.

\section{Literature Review}

\subsection{E-commerce definition}

E-commerce refers to the buying and selling of information, products and services via computer networks; it focuses on business activities conducted through electronic intervention, such as sharing information, promoting business products, customer services, and other interrelated activities via technology applications such as e-mail, web portals, online banks, electronic fund transfers and payment gateways that back up these business activities [3].

\subsection{The antecedents of online purchase in e-commerce}

Customers' intention to purchase a product via e-commerce is influenced by many factors. Among them are pre-purchase services, transaction-related services, navigation experiences, attitude towards the web and purchase intention [4]. Pre-purchase services consist of product pricing, support of product search evaluation and web appearance [4]. According to previous study, product pricing and 
website appearance have been found to influence customer intention to purchase over the internet [5]-[9].

Transaction-related services consist of the billing and paying mechanism, delivery arrangement, security and privacy [4]. According to previous study, billing and paying mechanism, delivery arrangement and security and privacy have been found to influence online customer intention [7][11].

Both pre-purchase and transaction-related services form the navigation experience [4]. Also, the navigation arrangement sequentially influences the customers' attitude towards the web and their purchase intention [4], [12], [13].

\section{Method}

Data were collected via an online survey of 319 Muslim women who wear hijab. The respondents were exposed to both conventional and Islamic fashion e-commerce using the sites: hijup.com and zalora.co.id. The respondents were asked to evaluate their pre-purchase and transaction-related services, navigation experiences, attitude towards the web and purchase intention soon after they tried to purchase fashion products from both websites.

\section{Analysis}

\subsection{Descriptive analysis}

Most of the respondents were high school graduates (66.67\%) aged between 17 and 22 years old $(80.50 \%)$, working as a student $(79.56 \%)$ and single (93\%). As most of the respondents were students, the researcher exercised caution as the results may be threatened by the sampling bias issue.

Table 1. Descriptive Statistics

\begin{tabular}{|c|c|c|c|}
\hline Variable & Description & Number & Percentage \\
\hline \multirow[t]{6}{*}{ Education } & Junior high school & 16 & 5,03 \\
\hline & Senior high school & 166 & 52,20 \\
\hline & Diploma & 26 & 8,18 \\
\hline & Bachelor & 104 & 32,70 \\
\hline & Master & 6 & 1,89 \\
\hline & Total & 318 & 100 \\
\hline \multirow[t]{8}{*}{ Age } & $17-22$ years old & 256 & 80,50 \\
\hline & $23-28$ years old & 45 & 14,15 \\
\hline & 29-34 years old & 4 & 1,26 \\
\hline & $35-40$ years old & 4 & 1,26 \\
\hline & 41-46 years old & 5 & 1,57 \\
\hline & 47-52 years old & 2 & 0,63 \\
\hline & $>53$ years old & 2 & 0,63 \\
\hline & Total & 318 & 100 \\
\hline \multirow{6}{*}{ Occupation } & Student & 253 & 79.56 \\
\hline & Housewive & 11 & 3,46 \\
\hline & Government Employee & 29 & 9,12 \\
\hline & Entrepreneur & 9 & 2,83 \\
\hline & Others & 16 & 5,03 \\
\hline & Total & 318 & 100,00 \\
\hline \multirow[t]{3}{*}{ Marital Status } & Single & 296 & 93.08 \\
\hline & Married & 22 & 6.91 \\
\hline & Total & 318 & 100 \\
\hline
\end{tabular}




\subsection{Comparison of mean between conventional vs. Islamic e-commerce}

The researcher conducted a paired sample t-test to examine the difference in customers' perception of the antecedents of their purchase intention with respect to fashion products with both conventional and Islamic dimensions (Table 2). The results of mean comparison indicate that Muslim women who wear hijab/veil still have much higher preferences for conventional e-commerce rather than Islamic e-commerce.

Table 2. Paired Sample T-Test Conventional vs Islamic E-Commerce.

\begin{tabular}{llccc}
\hline Pair & Comparison & $\begin{array}{c}\text { Mean } \\
\text { Conventional }\end{array}$ & Mean Islamic & Sig \\
\hline Pair 1 & Conventional PP - Islamic PP & 4.78 & 4.65 & .001 \\
\hline Pair 2 & Conventional SEC - Islamic SEC & 4.78 & 4.73 & .233 \\
\hline Pair 3 & Conventional WA - Islamic WA & 4.90 & 4.78 & .004 \\
\hline Pair4 & Conventional BP - Islamic BP & 5.05 & 4.82 & .000 \\
\hline Pair 5 & Conventional DA - Islamic DA & 4.85 & 4.71 & .002 \\
\hline Pair 6 & Conventional SP - Islamic SP & 4.85 & 4.70 & .004 \\
\hline Pair 7 & Conventional NAV - Islamic NAV & 4.92 & 4.75 & .000 \\
\hline Pair 8 & Conventional ATT - Islamic ATT & 4.77 & 4.56 & .000 \\
\hline Pair 9 & Conventional INT - Islamic INT & 4.49 & 4.38 & .048 \\
\hline
\end{tabular}

Note: $\mathrm{DA}=$ Delivery arrangement; $\mathrm{SEC}=$ Support and product search evaluation; $\mathrm{BP}=\mathrm{Billing}$ of payment; $\mathrm{SP}=\mathrm{Security}$ and privacy; WA: Web appearance; $\mathrm{PP}=$ Product pricing; NAV=Navigation experience, ATT=Attitude towards the web; INT=Intention.

Based on table 2, significant differences between conventional and Islamic e-commerce were found in terms of delivery arrangement, billing and payment, security and privacy, web appearance, product pricing, navigation experience, attitude towards the web and intention ( $\mathrm{Sig}<0,05)$. The statistical result also shows that customers of both conventional and Islamic banks have similar perceptions regarding support and product search evaluation. In other words, there is no difference between a conventional and Islamic bank in terms of the support and product search evaluation variable $(\mathrm{Sig}=0.233)$.

\section{Summary}

Despite the Islamic fashion industry experiencing very progressive growth, most Muslims who wear hijab still consider conventional e-commerce to be much more beneficial to customers in terms of delivery arrangement, billing and payment, security and privacy, web appearance, product pricing, navigation experience, attitude towards the web and intention, except for support and product search evaluation.

\section{Acknowledgement}

This research was supported financially by a PITTA Grant to Directorate Research and Community Services Universitas Indonesia.

\section{References}

[1] arabianbusiness.com, "Islamic fashion market set to be worth $\$ 327$ bn by 2020," 2015. [Online]. Available: http://www.arabianbusiness.com/islamic-fashion-market-set-be-worth-327bn-by2020-604854.html. [Accessed: 02-Apr-2017].

[2] A. Jadallah, "The world's fastest-growing population is also a massively untapped food and fashion market," 2017. [Online]. Available: https://qz.com/888830/the-worlds-fastestgrowing-population-is-also-a-massively-untapped-food-and-fashion-market/. [Accessed: 02Apr-2017]. 
[3] S. C. Lim, A. S. Baharudin, and R. Q. Low, "E-commerce adoption in peninsular Malaysia: Perceived strategic value as moderator in the relationship between perceived barriers, organization readiness and competitor pressure," J. Theor. Appl. Inf. Technol., vol. 91, no. 2, pp. 228-237, 2016.

[4] I. Küster, N. Vila, and P. Canales, "How does the online service level influence consumers' purchase intentions before a transaction? A formative approach," Eur. J. Manag. Bus. Econ., vol. 25, no. 3, pp. 111-120, 2016.

[5] P. Jiang and B. Rosenbloom, "Customer intention to return online: price perception, attributelevel performance, and satisfaction unfolding over time,” Eur. J. Mark., vol. 39, no. 1/2, pp. 150-174, 2005.

[6] R. H. Hall and P. Hanna, "The impact of web page text-background colour combinations on readability, retention, aesthetics and behavioural intention," Behav. Inf. Technol., vol. 23, no. 3, pp. 183-195, 2004.

[7] X. Liu, M. He, F. Gao, and P. Xie, "An empirical study of online shopping customer satisfaction in China: a holistic perspective," Int. J. Retail Distrib. Manag., vol. 36, no. 11, pp. 919-940, 2008.

[8] M. D. Clemes, C. Gan, and J. Zhang, "An empirical analysis of online shopping adoption in Beijing, China,” J. Retail. Consum. Serv., vol. 21, no. 3, pp. 364-375, 2014.

[9] K.-C. Chang, "The Impact of Website Quality and Perceived Trust on Customer Purchase Intention in the Hotel Sector: Website Brand and Perceived Value as Moderators," Int. J. Innov. Manag. Technol., vol. 5, no. 4, pp. 255-260, 2014.

[10] C. Liu, J. T. Marchewka, J. Lu, and C. S. Yu, "Beyond concern-a privacy-trust-behavioral intention model of electronic commerce," Inf. Manag., vol. 42, no. 2, pp. 289-304, 2005.

[11] Y. Eri, M. Islam, and K. Daud, "Factors that Influence Customers' Buying Intention on Shopping Online,” Int. J. Mark. Stud., vol. 3, no. 1, pp. 128-139, 2011.

[12] Y.-K. S. M. Norton, "Attitude toward internet web sites, online information search, and channel choices for purchasing," J. Fash. Mark. Manag. an Int. J., vol. 11, no. 4, pp. 571-586, 2007.

[13] L. Davis Burns, N. J. Rabolt, and H.-J. Park, "Fashion innovativeness, materialism, and attitude toward purchasing foreign fashion goods online across national borders: The moderating effect of internet innovativeness," J. Fash. Mark. Manag., vol. 11, no. 4, pp. 571-586, 2007. 